\title{
Lokalne czasopisma Patriotycznego Ruchu Odrodzenia Narodowego w poznańskiem w latach 1983-1989
}

Streszczenie: Autor scharakteryzował przykładowe czasopisma Patriotycznego Ruchu Odrodzenia Narodowego (PRON), jakie ukazywały się w dawnym województwie poznańskim w latach 1983-1989. Należały do nich następujące miesięczniki: „Echa Opalenickie” (1983-1989), „Głos Śremski” (1984-1989), „Kórniczanin” (1988-1989), „Wiadomości Grodziskie” (1986-1989), „Wiadomości Nowotomyskie” (1986-1989), oraz dwumiesięcznik ,Ziemia Szamotulska” (1988-1989). Przedstawił inicjatorów tych wydawnictw oraz ich cele, zadania i zawartość, a także niektórych autorów materiałów prasowych.

Słowa kluczowe: Patriotyczny Ruch Odrodzenia Narodowego (PRON), lokalne czasopisma pronowskie, województwo poznańskie w latach 1983-1989

Specyficzną rolę w lokalnym nurcie inicjatyw prasowo-wydawniczych w latach osiemdziesiatych XX wieku odgrywały periodyki poszczególnych ogniw Patriotycznego Ruchu Odrodzenia Narodowego (1982-1989) - organizacji zainicjowanej w 1982 roku przez władze PRL-u i animowanej w kooperacji $\mathrm{z}$ licencjonowanymi podmiotami społecznymi, takimi jak: Stowarzyszenie PAX, Chrześcijańskie Stowarzyszenie Społeczne, Polski Związek Katolicko-Społeczny (Deklaracja, 1983; I Kongres, 1983). Znaczną część objętości tych czasopism poza informacjami o charakterze społeczno-politycznym zajmowały materiały dotyczące historii regionu, wybitnych postaci, zabytków, działalności stowarzyszeń społeczno-kulturalnych, dorobku miejscowych animatorów kultury i twórców, które mogły w tamtym czasie ukazywać się legalnie między innymi pod politycznym patronatem Patriotycznego Ruchu Odrodzenia Narodowego (PRON).

W dawnym województwie poznańskim, które wyraźnie wyróżniało się pod tym względem, lokalne Rady PRON-u w Grodzisku Wlkp., Kórniku, Nowym Tomyślu, Opalenicy, Szamotułach i Śremie wydawały ta- 
kie miesięczniki, jak: „Echa Opalenickie” (1983-1989), „Głos Śremski” (1984-1989), „Kórniczanin” (1988-1989), „Wiadomości Grodziskie” (1986-1989), ,Wiadomości Nowotomyskie” (1986-1989), oraz dwumiesięcznik „Ziemia Szamotulska” (1988-1989). Być może w Poznańskiem, stanowiącym jądro historycznego regionu wielkopolskiego, wyraźniej niż w innych regionach Polski uwidoczniły się, zgodnie z XIX-wiecznymi ideami pozytywizmu oraz pracy organicznej, tendencje poszukiwania w najważniejszych sprawach publicznych społecznej zgody poprzez rozumny kompromis, który nie eliminując możliwości wyrażania naturalnych różnic, istniejących pomiędzy ludźmi, na czele stawia jednak dobro wspólne - chociaż ułomne. Wyrazem tej postawy są właśnie pronowskie lokalne inicjatywy prasowo-wydawnicze, w których zawartości znajdowało się wiele materiałów kontestujących ówczesną sytuację zarówno społeczno-polityczna, jak i gospodarcza, oraz poruszających niewygodne dla władzy wydarzenia historyczne. W ten sposób stały się te czasopisma także jednym z niewielu legalnie działających środowisk, które w sposób wyraźny - nie podważając jednak wprost ustrojowych pryncypiów PRL-u - poszukiwały innej drogi rozwoju naszego kraju. Być może była to droga do „socjalizmu z ludzką twarzą”, którego domagali się między innymi strajkujący robotnicy Sierpnia 1980 roku.

\section{„Echa Opalenickie” (1983-1989)}

Pierwszym wielkopolskim czasopismem pronowskim, być może także pierwszym w Polsce, jak twierdzi Sylwester Dziki (1991, s. 71), które odtwarzało w ówczesnych warunkach politycznych zagubioną w PRL-u ideę prasy lokalnej, były „Echa Opalenickie” wydane na 21 dni przed zniesieniem stanu wojennego, a mianowicie 1 lipca 1983 roku pod egidą Rady MiejskoGminnej PRON w Opalenicy. Czasopismo nie posiadało wówczas formalnego zezwolenia na druk i rozpowszechnianie od Głównego Urzędu Kontroli Publikacji i Widowisk (GUKPiW), o które wystapiono dopiero 15 lipca 1983 roku. Zezwolenie takie GUKPiW wydał 11 sierpnia 1983 roku.

Inicjatorem czasopisma był Andrzej Silski, członek poznańskiego Klubu Dziennikarzy Młodzieżowych, prowadzący „Koło Młodych Twórców" przy opalenickim Domu Kultury. Rada Miejsko-Gminna PRON w Opalenicy, którą kierował dr Bronisław Kaczmarek, powołała kolegium redakcyjne czasopisma, w którego skład weszli: Zygmunt Duda (redaktor naczelny, ówczesny dyrektor Miejsko-Gminnego Ośrodka Kul- 
tury w Opalenicy), Stefan Krajewski, Ireneusz Kwiatkowski (do września 1983), Jeremi Mroczek (do kwietnia 1985), Andrzej Silski (zastępca redaktora naczelnego do sierpnia 1988) oraz Andrzej Szumiński (do maja 1984). Od lipca 1984 roku do redakcji dołączyła Małgorzata Kasperczak, zaś od października 1985 roku Bogumił Wojcieszak, a następnie Feliks Straburzyński i Wanda Wachowiak-Kreczko. Natomiast od stycznia 1989 roku trzyosobowy skład redakcji tworzyli: Zygmunt Duda (redaktor naczelny), Małgorzata Kasperczak (sekretarz redakcji) oraz Bogumił Wojcieszak. Miesięcznik, który kolportowano w mieście i gminie Opalenica (obecnie pow. nowotomyski), posiadał format A4, objętość 4-8 stron i nakład 1000 egzemplarzy.

W pierwszym numerze nowego opalenickiego wydawnictwa zarysowano jego najważniejsze zadania, pisząc: „Gazeta, którą państwo macie przed sobą jest swoistym ewenementem $\mathrm{w}$ historii naszego miasta. Rzadkością bowiem jest, aby w środowisku gminnym wychodziła lokalna prasa. «Echa Opalenickie» powstały z inicjatywy Miejsko-Gminnej Rady Patriotycznego Ruchu Odrodzenia Narodowego i są jej organem prasowym. [...] Na łamach pisma przedstawiać będziemy aktualne poczynania Miejsko-Gminnej Rady PRON w zakresie jej statutowych kompetencji i możliwości. Zajmować się będziemy problemami nurtującymi środowisko opalenickie" (Od redakcji, 1983, s. 1). Redakcji zależało także na tym, by łamy czasopisma były „widownią kontrowersyjnych wypowiedzi i ostrych, acz kulturalnych polemik mających oczywiście na celu konstruktywny postęp w naszym miejsko-gminnym życiu i przybliżenie problemów władz społeczeństwu i na odwrót" (Mroczek, 1983, s. 2). Po wydaniu ośmiu numerów periodyku znowu podjęto temat jego zadań i celów, stwierdzając: „Powołany do życia miesięcznik «Echa Opalenickie» jest nie tylko trybuną naszego ruchu, ale i forum spraw regionu opalenickiego. Toteż zamierzeniem naszym jest, aby czasopismo to było naprawdę pismem wszystkich mieszkańców miasta i wsi, abyśmy razem je kształtowali i decydowali o tym, jaki będzie zakres poruszanych tematów. Chcemy, aby pismo to otwarte było na wszystkie prawdziwe a niepozorne problemy. (...) Chcemy w naszym piśmie zwalczać przejawy patologii społecznej, takie jak bierność, alkoholizm, bezmyślność, znieczulicę, panoszący się brud, bałagan i głupotę" (Kaczmarek, 1984, s. 4). Natomiast po roku działalności „Ech Opalenickich”, ich inicjator, Andrzej Silski (1984, s. 1, 3), napisał: „Biorąc pod uwagę fakt, że żaden członek naszej redakcji nie jest dziennikarzem zawodowym, a większość nie miała przedtem żadnego kontaktu z prasowym piórem, nie można 
wymagać od nas nieprzeciętności. Nie oznacza to jednak, że to jest już wszystko na co nas stać. Ciaggle się uczymy dziennikarskiego rzemiosła, starając się, aby gazeta miała coraz wyższy poziom zamieszczanych materiałów. [...] W rzeczywistości redagowanie «Ech» to ciężka społeczna praca, którą znają sami tylko «redaktorzy»".

Jednym z głównych animatorów miesięcznika, obok Andrzeja Silskiego, był Zygmunt Duda, dyrektor miejscowego ośrodka kultury, przewodniczący komisji interwencji społecznych Rady Miejsko-Gminnej PRON w Opalenicy, od 1985 roku wiceprzewodniczący Rady Miejsko-Gminnej PRON, a także opalenicki społecznik i regionalista ${ }^{1}$, który wspominając tamte czasy, stwierdził: „Pojawienie się w lipcu 1983 roku czterostronicowego pisma, formatu A4, pod tytułem «Echa Opalenickie» w nakładzie 1000 egzemplarzy, finansowanego przez Radę Miejsko-Gminną PRON w Opalenicy, rozpowszechnianego przez kioski «Ruch» i sklepy geesowskie, przyjęto ze zdziwieniem i niedowierzaniem, że w mieście pojawia się miejscowe słowo drukowane. [...] Na łamach «Echa Opalenickiego» miejscowi regionaliści odkrywali przeszłość «małej ojczyzny» [...] Podejmowano tematy polityczne, sportowe, gospodarcze, oświatowe. [...] Obowiązek prezentacji tekstów w cenzurze poznańskiej wypełniał niezmiennie redaktor naczelny.

1 Zygmunt Duda jest laureatem poznańskiej Nagrody Wojewódzkiej w Dziedzinie Upowszechniania Kultury za rok 1983. Początkowo pracował jako nauczyciel, później został dyrektorem Miejsko-Gminnego Ośrodka Kultury w Opalenicy, gdzie dał się poznać jako sprawny organizator kultury - zespołów regionalnych „Rudniczanki” i „Alibanki” w Rudnikach, „Harmonia” w Wojnowicach, zespołu rodzinnego w Kopankach, zespołu folklorystycznego w Niegolewie, ogniska muzycznego przy Wiejskim Domu Kultury w Rudnikach, którego był twórcą i współorganizatorem. Zygmunt Duda jest autorem szeregu artykułów i opracowań zwartych, które dotyczyły regionu opalenickiego, między innymi: 600 lecie parafii św. Mateusza w Opalenicy. Kalendarium (2001); Cmentarz parafialny w Opalenicy (1997); Kapliczki na opalenickiej ziemi (1999); Krzyże opalenickiej ziemi (1998); Opalenica w malarstwie (1988); Parafia opalenicka w okresie okupacji (1996); Przydrożne figury i kapliczki na opalenickiej ziemi (1999); Stulecie światyni, dwudziestolecie parafi św. Józefa w Opalenicy 1900-2000 (2001); Uścięcice. Zarys dziejów wsi nad Mogilnica (2013); Z dziejów gminy ewangelickiej w Opalenicy 1893-1945 (2000); Zarys dziejów klubu sportowego „,Promień” w Opalenicy 1924-1994 (1994). Jest on również współautorem wielu prac zbiorowych, na przykład: Z. Duda, A. Szumiński, Leśna kapliczka (Opalenica 1990); Z. Duda, M. Rezler, Miasto w latach 1945-1989, w: Dzieje Opalenicy (Poznań 1993), s. 236-317; Z. Duda, B. Wojcieszak, Materiaty do kalendarium dziejów Opalenicy 1393-1795 (Opalenica 1987); Z. Duda, B. Wojcieszak, Materiały do kalendarium dziejów Opalenicy w latach zaborów (Opalenica 1987); B. Wojcieszak, Z. Duda, Zarys dziejów kościoła i klasztoru Franciszkanów-Reformatów na Wyrwale w Woźnikach (Opalenica 1998). 
Ukazały się trzy krótkie artykuły poza cenzura, dotyczyły Katynia, Piłsudskiego, «noża w plecy» w 1939 roku... i udało się to wszystko. Miejscowe władze tych tekstów «nie zauważyły». Podejmowano tematykę wiejską, zakładów pracy, przez co zyskiwano czytelników tych środowisk. «Echa Opalenickie» jako pierwsze (czy jedyne?) otrzymały odznakę honorową za zasługi w rozwoju województwa poznańskiego (21 czerwca 1989) [...] Czytelnictwo sięgało w początkowych latach 70-90\% nakładu [...] Jako redaktor naczelny byłem zapraszany oficjalnie do obsługi zebrań, narad, uroczystości... [...] «Echa Opalenickie» zajmowały się interwencja, przyjmowały skargi, ingerowały w sprawy. Były za to podziękowania. Pismo promowało ludzi i sprawy, służyło radą i poradą. Mieliśmy swego prawnika, lekarza-społecznika, budowlańca, telefon interwencyjny, dyżurnego fotografa" (Kowalczyk, 2002, s. 243). Różnorodną zawartość miesięcznika od maja 1984 roku (numer 5) wzbogacała rubryka „Rodem z naszej ziemi”, prowadzona przez Zygmunta Dudę, w której przedstawiano sylwetki wybitnych mieszkańców ziemi opalenickiej, w tym między innymi: Bernarda Chrzanowskiego, Artura i Leszka Gustowskich, Józefa Karge, Stanisława Obsta, Jana Sokołowskiego, Ireneusza Wierzejewskiego, Edwarda Woźniaka. Natomiast w grudniu 1984 roku okazjonalnie pojawiła się w czasopiśmie specjalna czterostronicowa wkładka pod tytułem „Dodatek Historyczny", gdzie Zygmunt Duda omawiał dzieje zamku opalenickiego, a Bogumił Wojcieszak biografię Katarzyny z Opalińskich, żony króla Polski Stanisława Leszczyńskiego, urodzonej w Opalenicy.

Miesięcznik „Echa Opalenickie” ukazywał się jako organ prasowy Rady Miejsko-Gminnej PRON w Opalenicy i w tej formule wydawniczej dotrwał do listopada 1989 roku - ukazało się w tym czasie 75 numerów (Andrzejewski, 2003, s. 4-6; Silski, 2013, s. 7). 21 czerwca 1989 roku czasopismo zostało wyróżnione odznakę honorową ,Za zasługi w rozwoju województwa poznańskiego".

Pisali w ówczesnym miesięczniku lokalni działacze polityczni i społeczni, animatorzy kultury, bibliotekarze, nauczyciele, pracownicy miejscowych przedsiębiorstw, spółdzielni, zakładów, lekarze, prawnicy, urzędnicy, wśród których byli między innymi: Bogdan Adamczak, Bogdan Andrzejewski (I sekretarz Komitetu Miejsko-Gminnego PZPR w Opalenicy), Stanisław Andrzejewski, Stefan Bogucki, Kazimierz Czarnecki, Jerzy Czternasty, Janusz Daszkiewicz, Kazimierz Drążkiewicz, Zygmunt Duda, Stefan Dziamski, Kazimierz Filipiak, Janusz Galas, Maria Galas, Bronisław Kaczmarek, Zdzisław Kawczyński, Bożena Konieczna, Zdzisław Kościański, Zygmunt Kościański, Tadeusz Kowalski, 
Wanda Kreczko-Wachowiak, Stefan Krajewski, Stanisław Kroma, Ireneusz Kwiatkowski, Irena Maik, Andrzej Mainka, Joel Matuszek (Naczelnik Miasta i Gminy Opalenica), Jeremi Mroczek, Maria Mrówczyńska, Władysław Nowak, Zdzisław Pocztowy, Marian Przybylski, Andrzej Silski, Bronisław Stachecki, Feliks Straburzyński, Zygmunt Swajdo, Andrzej Szumiński, Tadeusz Śledzikowski, Bogdan Uryzaj, Zenon Walkowiak, Henryk Wojciechowski, Bogumił Wojcieszak, Henryk Zimny.

Po kilkumiesięcznej przerwie we wrześniu 1990 roku wydawanie miesięcznika „Echa Opalenickie” przejęła spółka cywilna „ANSIGBO”, którą powołali Zygmunt Duda, Bogumił Wojcieszak oraz Andrzej Szumiński, zaś od stycznia 1992 roku gmina Opalenica, która wydaje czasopismo do dzisiaj (Bobowska, 2008, s. 12-14; Kowalczyk, 2012, s. 220). Do lipca 1999 roku redakcją kierował Zygmunt Duda.

\section{„Głos Śremski” (1984-1989)}

W ślad za Opalenicą poszły inne środowiska lokalne. W lipcu 1984 roku ukazał się pierwszy numer „Głosu Śremskiego”, miesięcznika Rady Miejsko-Gminnej PRON w Śremie. Wcześniej jednak, albowiem 17 czerwca 1984 roku, pojawiło się okolicznościowe wydanie „Głosu Śremskiego”. Inicjatorem tytułu był między innymi Karol Gostomski, miejscowy działacz społeczno-kulturalny i polityczny, którego wybrano redaktorem naczelnym czasopisma ${ }^{2}$. Natomiast pierwszym przewodniczącym zespołu redakcyjnego został Adam Podsiadły ${ }^{3}$, zaś jego pozostały skład tworzyli: Stanisław Falecki, Karol Gostomski (zastępca przewodniczącego, od 1986 roku przewodniczący), Wojciech Górski, Gabriel

${ }^{2}$ Karol Gostomski w 1969 roku objął obowiązki dyrektora Powiatowej i Miejskiej Biblioteki Publicznej w Śremie, które pełnił aż do swojej śmierci w 2003 roku.

${ }_{3}$ Adam Podsiadły, nauczyciel, historyk, dziennikarz i regionalista, był autorem pracy (mps) Powiat śremski w latach okupacji hitlerowskiej 1939-1945 (Śrem 1974) oraz współautorem (z S. Jurga) opracowania pod tytułem Straty osobowe harcerstwa śremskiego 1939-1945 (Śrem 1982). W późniejszych latach pełnił funkcję dyrektora Muzeum Śremskiego, redaktora i dziennikarza „Gazety Poznańskiej”, „Merkuriusza Leszczyńskiego”, „Panoramy Leszczyńskiej”, „Przeglądu Regionalnego”, „Zeszytów Osieckich". Adam Podsiadły jest autorem monografii, Śremianin w rektorskiej todze. Heliodor Święcicki (1854-1923) lekarz, naukowiec, profesor Uniwersytetu Poznańskiego (Śrem 2010) oraz Zarys działalności szkolnego schroniska młodzieżowego „Morena” w Osiecznej 1981-2011 (Osieczna 2011), a także współautorem (z D. Płygawko) Stownika biograficznego Śremu (Śrem 2008). 
Jasiński, Jerzy Kondras, Renata Kościelniak, Ewa Nowicka (sekretarz redakcji), Urszula Poźniak, Zbigniew Skrzypczak, Irena Staszewska, Kazimierz Zastawny. Nad stroną techniczną periodyku czuwali Eugeniusz Ferster, Zbigniew Jarych, Maciej Waraczewski, zaś za ilustracje odpowiadał Krzysztof Jurga (fotoreporter).

Rada Miejsko-Gminna PRON w Śremie 11 października 1984 roku otrzymała powtórne tymczasowe zezwolenie GUKPiW ważne w 1985 roku na druk i rozpowszechnianie w mieście i gminie Śrem miesięcznika „Głos Śremski” w nakładzie do 2000 egzemplarzy, objętości do 8 stron formatu A4. Natomiast stałe zezwolenie GUKPiW wydał 28 października 1985 roku. Czasopismo ukazywało się w tej formule wydawniczej od lipca 1984 roku do maja 1989 roku i było rozpowszechniane na obszarze byłego powiatu śremskiego, obejmując kolportażem gminy: Brodnica, Dolsk, Książ Wlkp. i Śrem.

W pierwszym numerze „Głosu Śremskiego” w następujących słowach przedstawiono jego cele i zadania: „Zespół Redakcyjny powołany w marcu br. postawił gazecie następujące cele: szeroką prezentację dorobku przemian i perspektyw rozwojowych środowiska na płaszczyznach - życia społeczno-politycznego, gospodarczego i kulturalnego. Wyrażanie krytycznego głosu i opinii społeczeństwa wobec problemów dnia dzisiejszego w miejscu zamieszkania i pracy. Aktywizację mieszkańców miasta i gminy w kierunku społecznej działalności na rzecz regionu. Informowanie o bieżących wydarzeniach regionalnych" (Od redakcji, 1984, s. 1). W zawartości „Głosu Śremskiego” znajdziemy dużo materiałów dotyczących historii (Tetzlaf, 1985, s. 5; Walczak, 1986, s. 6) i dorobku społeczno-kulturalnego ziemi śremskiej (Falecki, 1984, s. 4-5; Zastawny, 1985, s. 7), w tym wspomnienia powstańców wielkopolskich (Grabowski, 1988, s. 1-2) i żołnierzy II wojny światowej (Wawrzyniak, 1985, s. 4-5) oraz biogramy wybitnych śremian (Podsiadły, 1988, s. 3; 1987, s. 5; Zastawny, 1985, s. 6-7; 1986, s. 4).

Na łamach miesięcznika głos zabierali między innymi: Stanisław Falecki, Karol Gostomski, Wojciech Górski, Gabriel Jasiński, Jerzy Koterba, Zenon Osiński, Danuta Płygawko, Adam Podsiadły, Józef Podsiadły, Urszula Poźniak, Andrzej Ratajczak, Zbigniew Skrzypczak, Irena Staszewska, Roman Szafrański, Marceli Szczęsny, Zbigniew Szmidt, Krzysztof Walczak, Mieczysław J. Wawrzyniak, Kazimierz Zastawny.

Od czerwca 1989 roku do stycznia 1991 roku „Głos Śremski” wydawało Towarzystwo Miłośników Śremu (Grobelna, 2012, s. 59-64), po czym miesięcznik przestał się ukazywać. 


\section{„Wiadomości Grodziskie” (1986-1989)}

W latach 1986-1989 ukazywał się w mieście i gminie Grodzisk Wlkp. miesięcznik Patriotycznego Ruchu Odrodzenia Narodowego „Wiadomości Grodziskie", wydawany początkowo w formacie A4, objętości 4 stron i nakładzie 1000 egzemplarzy. Z wnioskiem do GUKPiW o zezwolenie na druk i rozpowszechnianie miesięcznika „Wiadomości Grodziskie” wystąpiła Miejsko-Gminna Rada PRON w Grodzisku Wlkp. w listopadzie 1985 roku, zaś zgodę otrzymano 6 stycznia 1986 roku. Na redaktora naczelnego zaproponowano Jana Kozę, który był wówczas sekretarzem Urzędu Miasta i Gminy w Grodzisku Wlkp. Na początku listopada 1986 roku zwrócono się ponownie z wnioskiem do GUKPiW o zwiększenie objętości „Wiadomości Grodziskich" z 4 do 8 stron formatu A4. Tłumaczono to zarówno wzrostem zainteresowania miesięcznikiem ze strony mieszkańców, szczególnie młodzieży, dla której zamierzano utworzyć stałą rubrykę, jak i pragnieniem szerszego potraktowania problematyki związanej z historią ziemi grodziskiej. Zezwolenie takie GUKPiW wydał 10 listopada 1986 roku. Natomiast w maju 1988 roku wystapiono z następnym wnioskiem do GUKPiW, tym razem o zwiększenie nakładu „Wiadomości Grodziskich” do 1500 egzemplarzy, na co prezes GUKPiW wyraził zgodę.

W pierwszym numerze „Wiadomości Grodziskich”, który ukazał się w styczniu 1986 roku, wyszczególniono główne zadania miesięcznika, do których zaliczono ,przekazywanie grodziskiemu społeczeństwu wszystkich spraw związanych z życiem politycznym, społecznym i gospodarczym naszego terenu. Pragniemy na bieżąco informować naszych Obywateli o tym co dzieje się lub dziać będzie w mieście i gminie Grodzisk Wlkp. Będziemy też przedstawiać zamierzenia i osiagnięcia lokalnej organizacji PRON. Łamy naszej gazety służyć będą szlachetnej idei porozumienia narodowego, zacieśnieniu więzów między ludźmi dobrej woli, którym na sercu leży rozwój naszego miasta i gminy. Na naszych szpaltach [...] nie może zabraknąć miejsca dla spraw młodzieży, kultury i sportu. Mamy też nadzieję, że miesięcznik ten będzie jednym z istotnych elementów aktywizujących zakładowe i środowiskowe ogniwa PRON" (Od redakcji, 1986, s. 1).

Inicjatorami „Wiadomości Grodziskich” i jego animatorami byli: wspomniany Jan Koza ${ }^{4}$, który stanął na czele redakcji, oraz Jan Gnus,

4 Jan Koza był w późniejszym okresie współautorem (z Dariuszem Matuszewskim) szeregu publikacji regionalistycznych dotyczących ziemi grodziskiej, w tym na przykład: Między Starym i Nowym Rynkiem (1998), Okolice przedmieścia Bernardyńskiego (2000), Stary Rynek (1997), Wokót Nowego Rynku (1999). 
zastępca redaktora naczelnego (jednocześnie przewodniczący MiejskoGminnej Rady PRON w Grodzisku Wlkp. i pracownik Wojewódzkiego Ośrodka Postępu Rolniczego w Sielinku, który kandydował między innymi na posła w wyborach czerwcowych 1989 roku). Osoby te były znanymi w środowisku działaczami społeczno-politycznymi i kulturalnymi. W składzie redakcji znaleźli się ponadto: Kazimierz Borowski, Bogumiła Michalak, A. Świekatowski (redaktor techniczny), Elżbieta Urbaniak. Od 1988 roku rozpoczął współpracę z pismem Olgierd Tomaszewski, autor szaty graficznej miesięcznika i twórca stałej rubryki „Ze szkicownika grodziskiego".

Na zawartość „Wiadomości Grodziskich” składały się artykuły, kronika, notatki, opracowania, sprawozdania, sylwetki, w których przedstawiano również dzieje ziemi grodziskiej oraz jej walory kulturowe i turystyczno-krajoznawcze, a także dorobek instytucji publicznych, jednostek gospodarczych, organizacji społecznych i zainteresowania mieszkańców. Czasopismo wydawało także specjalne dodatki tematyczne, na przykład wraz z numerem 4 z 1987 roku kolportowano 4-stronicowe opracowanie Marii Dworzyńskiej, Antoniego Kłaka i Elżbiety Urbaniak pod tytułem 60 lat Gimnazjum i Liceum im. Juliusza Stowackiego w Grodzisku Wlkp. W 1987 roku publikowano w „Wiadomościach Grodziskich” również fragmenty powieści Gerarda Górnickiego o Powstaniu Wielkopolskim 1918-1919 pod tytułem Bitwa szalała do wieczora („Wiadomości Grodziskie", 1987). Zamieszczano także twórczość poetycką miejscowych autorów, na przykład Jarosława Czechowskiego, Iwony Gabryelczyk, Zbigniewa Stasika.

Na łamach „Wiadomości Grodziskich” pisali między innymi: Piotr Berger, Marian Bochyński, Kazimierz Borowski, Jerzy Chrzanowski, Władysław Chwalisz (ówczesny Naczelnik Miasta i Gminy Grodzisk Wlkp., późniejszy starosta powiatu grodziskiego), Jarosław Czechowski, Jan Gnus, Zdzisław Gulik, Jędrzej Jagaciak, Zdzisław Jankowski, Antoni Kłak, Jan Koza, Albin Łącki ${ }^{5}$, Dariusz Matuszewski ${ }^{6}$, Bogumiła Michalak, Bolesław Milczyński, E. Pawłowski, Olgierd Tomaszewski, Elżbieta Urbaniak, Jerzy Weryszko.

5 Szerzej o biografii i dorobku twórczym Albina Łąckiego zob.: Autorzy wielkopolscy. Informator, oprac. J. Banaszak, U. Bzdawka, Poznań 1991, s. 61-62; Cz. Olejnik, Wolsztyński stownik biograficzny, t. 2, Wolsztyn 2007, s. 165-168.

${ }^{6}$ Dariusz Matuszewski jest autorem szeregu publikacji regionalnych, między innymi: Kurkowe Bractwo Strzeleckie w Grodzisku Wielkopolskim 1646-1947 (Grodzisk Wielkopolski 2000). 
Po 1989 roku „Wiadomości Grodziskie” ukazywały się jako miesięcznik prywatny, który w tej formule wydawniczej przetrwał do grudnia 1991 roku.

\section{„Wiadomości Nowotomyskie” (1986-1989)}

Od Miejsko-Gminnej Rady PRON w Nowym Tomyślu wyszła inicjatywa wydawania „Wiadomości Nowotomyskich”, stąd 12 marca 1986 roku skierowano stosowny wniosek do GUKPiW, podpisany zarówno przez przewodniczącego Miejsko-Gminnej Rady PRON w Nowym Tomyślu, Edmunda Gawrona, jak i I sekretarza Komitetu Miejsko-Gminnego PZPR w Nowym Tomyślu, Józefa Piątasa. W zamierzeniu pomysłodawców czasopismo powinno służyć „popularyzacji działań PRON” oraz zmierzać do „ożywienia aktywności społeczno-politycznej mieszkańców" (Pismo, 1986). Jednym z głównych inicjatorów i animatorów czasopisma był między innymi Czesław Krolek (1935-2002), dyrektor Biblioteki Publicznej Miasta i Gminy Nowy Tomyśl (Biblioteka, 2000; Łozowski, 2003, s. 34-35) oraz zasłużony regionalista i działacz społeczno-kulturalny (prezes Nowotomyskiego Towarzystwa Kulturalnego) ${ }^{7}$. Zgodę GUKPiW na wydawanie miesięcznika pod nazwą „Wiadomości Nowotomyskie", w nakładzie do 1000 egzemplarzy, objętości do 8 stron formatu A4, otrzymano 19 maja 1986 roku. Jednak już 10 lipca 1986 roku wystąpiono do GUKPiW o zmianę formatu czasopisma z A4 na B4, na którą otrzymano zgodę 17 lipca 1986 roku. Z następnym wnioskiem do GUKPiW o zwiększenie nakładu miesięcznika do 3000 egzemplarzy zwrócono się 22 grudnia 1986 roku. Taką zgodę otrzymano 26 stycznia 1987 roku.

Miesięcznik „Wiadomości Nowotomyskie” w tej formule wydawniczej ukazywał się regularnie dokładnie trzy lata - od lipca 1986 roku do

${ }^{7}$ Czesław Krolek należał do grona osób szczególnie zasłużonych w sferze rozwoju sieci bibliotecznej i upowszechniania czytelnictwa w Nowym Tomyślu i powiecie nowotomyskim, za co już w 1964 roku został wyróżniony nagrodą indywidualną Miasta Poznania i Województwa Poznańskiego w dziedzinie upowszechniania kultury (Laureaci nagród Miasta Poznania i Województwa Poznańskiego $w$ dziedzinie upowszechniania kultury na rok 1964, „Kronika Miasta Poznania” 1966, nr 1, s. 87, 93-94). Czesław Krolek był także autorem opracowań historyczno-regionalistycznych, na przykład: Biblioteka w roku 50-lecia (Nowy Tomyśl 1996); Powstanie i rozwój bibliotek publicznych $w$ powiecie nowotomyskim w latach 1945-1975 (Nowy Tomyśl 2000). 
lipca 1989 roku - na obszarze gminy i miasta Nowy Tomyśl (nieregularnie także w gminach ościennych, jak: Kuślin, Lwówek i Rakoniewice). $\mathrm{Na}$ czele redakcji miesięcznika stał dr Henryk Błaż (1929-2000), pełniący wówczas funkcję wiceprzewodniczącego Miejsko-Gminnej Rady PRON, nowotomyski regionalista, dyrektor Liceum Ogólnokształcącego w Nowym Tomyślu (Henryk Błaż, 2001) ${ }^{8}$. Natomiast jego zastępcą został Stefan Wojtkiewicz (1935-2013), regionalista, pedagog i aktywny działacz harcerski ${ }^{9}$. Ponadto w skład kolegium redakcyjnego wchodzili: Kazimierz Bąbliński (redaktor techniczny, właściciel miejscowej drukarni „Kazimierz”), Gabriela Birka (fotoreporter), Henryk Helwing (późniejszy burmistrz Nowego Tomyśla), Lucyna Kończal (adiustatorka i późniejsza dyrektorka Miejskiej i Powiatowej Biblioteki Publicznej w Nowym Tomyślu), Czesław Krolek (sekretarz redakcji). Miesięcznik zwracał szczególną uwagę na zagadnienia społeczno-kulturalne, informował o inicjatywach miejscowego ośrodka kultury, bibliotek, szkół, organizacji młodzieżowych, przypominał chwalebne karty z historii ziemi nowotomyskiej i jej mieszkańców. Częścią czasopisma była wkładka „Na marginesie", którą redagowali członkowie sekcji dziennikarskiej miejscowego Klubu Miłośników Książki „Pro Libris”. Warto wspomnieć, iż czasopismo było gospodarzem ogólnopolskiego seminarium zespołów redakcyjnych gazet pronowskich, które odbyło się w dniach 27-28 maja 1988 roku w Kuźnicy Zbąskiej.

Na łamach „Wiadomości Nowotomyskich” pisał między innymi dr Zdzisław Kościański ${ }^{10}$, wielce zasłużony badacz i popularyzator regionu

${ }^{8}$ Doktor Henryk Błaż był również autorem wierszy, których zbiór pod tytułem Idę twoim śladem ukazał się w 1986 roku, wydany nakładem Biblioteki Publicznej Miasta i Gminy w Nowym Tomyślu.

9 Stefan Wojtkiewicz był zaangażowanym nauczycielem historii, harcmistrzem, przewodniczącym Rady Przyjaciół Harcerstwa w Nowym Tomyślu, przewodniczącym Harcerskiego Kręgu Seniora „Bratnich Rąk” i Kręgu Bractwa Zawiszy Czarnego w Nowym Tomyślu oraz autorem licznych podręczników metodycznych dla zuchów. Należał do grona aktywnych członków Nowotomyskiego Towarzystwa Kulturalnego, pełnił funkcję prezesa nowotomyskiego Koła Towarzystwa Pamięci Powstania Wielkopolskiego 1918-1919 oraz był członkiem Zarządu Głównego tego towarzystwa i wchodził w skład redakcji rocznika „Wielkopolski Powstaniec”. Był także autorem opracowań historyczno-regionalistycznych, w tym na przykład: Cmentarz Wojskowy Żotnierzy Radzieckich w Nowym Tomyślu (1985) oraz albumu, Piękno mojego miasta (1986), który zawierał jego rysunki wybranych obiektów architektonicznych Nowego Tomyśla.

${ }_{10}$ Zainteresowania badawcze doktora Zdzisława Kościańskiego ogniskują się na historii wojskowości i historii regionalnej, w szczególności na dziejach Powstania 
nowotomyskiego, regionalista wielkopolski, miłośnik kawalerii polskiej oraz Powstania Wielkopolskiego 1918-1919, który w miesięczniku popularyzował tematykę historyczno-kulturową (Kościański, 1986, s. 4; 1987, s. $12 ; 1988$, s. 5). Ponadto wśród autorów różnych materiałów, opracowań, sprawozdań, wspomnień, zamieszczanych na łamach „Wiadomości Nowotomyskich" byli na przykład: Henryk Adamczewski, Anna Beder, dr Henryk Błaż, Marian Czajka, Marek Czeszyński, Seweryn Drozdowski, Jerzy Dziamski, Teodozja Dziamska, Henryk Gabski, Aleksander Gorzelanny, Henryk Helwing, Maria Kornowska (Naczelnik Miasta i Gminy Nowy Tomyśl), Janina Kozłowska, Czesław Krolek, Czesław Królczak, Kazimierz Maciejkowicz, Karol Nowy, Tadeusz Pawlak ${ }^{11}$, Czesław Przybył, Regina Ratajczak, Bogumił Surkont, Zbigniew Świtała, Henryk Ta-

Wielkopolskiego 1918-1919. Jest on także niezmiernie aktywnym popularyzatorem historii i działaczem Towarzystwa Pamięci Powstania Wielkopolskiego 1918/1919, w którym pełni funkcję przewodniczącego Komisji Historycznej (inicjator cyklu prelekcji o Powstaniu Wielkopolskim w poznańskim „Odwachu”). Jego zaangażowana działalność na tym polu została wysoko oceniona i doceniona, w 2000 roku został bowiem uhonorowany nagrodą Towarzystwa Pamięci Powstania Wielkopolskiego 1918/1919 - „Doboszem Powstania Wielkopolskiego”. Doktor Zdzisław Kościański zamieszczał swoje artykuły, opracowania i sprawozdania w wielu czasopismach lokalnych i regionalnych („Echa Opalenickie”, „Grot. Zeszyty Historyczne”, „Kronika Wielkopolski”, „Przegląd Nowotomyski”, „Przegląd Wielkopolski”, „Wiadomości Nowotomyskie”, „Wielkopolski Powstaniec”, „Zegarynka”). Ponadto był autorem licznych opracowań zwartych o tematyce historycznej i charakterze historyczno-regionalistycznym, na przykład: Dwudziestolecie parafii pod wezwaniem Najświętszego Serca Pana Jezusa w Nowym Tomyślu (2001); Kadra dowódcza Powstania Wielkopolskiego 1918-1919 (1988); Organizacja i działania wojenne samodzielnej kawalerii polskiej w 1939 roku (2009). Doktor Zdzisław Kościański jest także współautorem wielu innych znaczących publikacji regionalnych, między innymi: Z. Kościański, Grodzisk Wielkopolski w dobie Powstania Wielkopolskiego 1918-1919, w: Grodzisk Wielkopolski. Zarys dziejów (Grodzisk Wielkopolski 1990); Z. Kościański, Powstanie Wielkopolskie 1918-1919 na terenie Lwówka i okolic, w: Nowego Tomyśla drogi do niepodległości (Nowy Tomyśl 2000); Z. Kościański, Cz. Krolek, Zarys dziejów kościoła Matki Bożej Nieustajacej Pomocy w Nowym Tomyślu (1896-1997) (Nowy Tomyśl 1997); Z. Kościański, E. Tomkowiak, Bukowianie w Powstaniu Wielkopolskim 1918-1919 (Poznań 2008); Trzeba było pójść.... Powiat nowotomyski w Powstaniu Wielkopolskim 1918-1919. Historia i pamięć, pod red. Z. Kościańskiego, B. Wojcieszaka (Nowy Tomyśl 2010).

11 Szerzej o działalności Tadeusza Pawlaka, nowotomyskiego pedagoga, działacza oświatowego i regionalnego, zob.: J. Szambelan, Tadeusz Pawlak (1919-1985), „Materiały - Informacje. Sprawozdania Regionalnej Izby Pamiątek Oświatowych” 1987, z. 2, s. 39-42. 
borski, Stefan Tasiemski, Zdzisław Wałęsa, Marian Wojciechowski, Stefan Wojtkiewicz, Edmund Żurek.

Zdzisław Kościański, jeden ze współtwórców „Wiadomości Nowotomyskich", w taki sposób skomentował warunki działalności czasopisma i jego redakcji w latach osiemdziesiątych: , «Wiadomości Nowotomyskie» zaczęły ukazywać się jeszcze w takim czasie, gdy konieczny był patronat PRON-u, nie miał on jednak de facto wielkiego wpływu na to pismo. $\mathrm{Na}$ pierwszej stronie czasem ukazywały się jakieś informacje z ich klucza, ale nie pisaliśmy o tym, co robi władza, ale jak żyją nowotomyślanie. Staraliśmy się dorzucić do dokumentowania tej rzeczywistości swój kamyk, a czasem dolać oliwy do ognia i pobudzić czytelników do myślenia. [...] Chociaż teksty były różnej jakości, to na pewno dawały obraz regionu, który inaczej uległby zapomnieniu. Wydawnictwo to miało czasem specyficzny smaczek, w niektórych tekstach używano specyficznego języka, ale w sumie pisaliśmy, co chcieliśmy" (Kupiec, 2010, s. 76).

„Wiadomości Nowotomyskie” od sierpnia 1989 roku przekształciły się w miesięcznik społeczno-kulturalny, a wkrótce, bowiem od października 1989 roku stały się czasopismem Nowotomyskiego Towarzystwa Kulturalnego. Pod jego skrzydłami pozostawały aż do końca swojej działalności, czyli do grudnia 1993 roku.

\section{„Kórniczanin” (1988-1989)}

Wydawany od maja 1988 roku „Kórniczanin”, miesięcznik MiejskoGminnej Rady PRON w Kórniku, zawdzięcza swoje powstanie między innymi prof. Jerzemu Wisłockiemu, ówczesnemu dyrektorowi Biblioteki Kórnickiej i przewodniczącemu Miejsko-Gminnej Rady PRON w Kórniku, który nawiązując do zadań takich lokalnych czasopism, stwierdził: „W Kórniku wszędzie otacza nas przeszłość i mamy obowiązek sięgać do tych wzorców, które nadawały sens codziennemu życiu. A tylko na szacunku dla tradycji możemy budować naszą przyszłość. [...] Dzisiejszy «Kórniczanin» ma nam przypominać zasady samorządu, sens zbiorowej pracy, nakłaniać do racjonalnego gospodarowania wspólnym majątkiem" (Wisłocki, 1988, s. 1). W tej formule organizacyjnej czasopismo przetrwało do 1989 roku i było rozpowszechniane w mieście i gminie Kórnik. Do grudnia 1989 roku na czele redakcji stał Edmund Melosik, później jego obowiązki przejął dr Kazimierz Krawiarz. Od 1990 roku wydawanie miesięcznika kontynuowały władze gminy Kórnik. 
Tematyka „Kórniczanina” ogniskowała się na dziejach i współczesności ziemi kórnicko-bnińskiej, dlatego pisano o lokalnej gospodarce, ważnych wydarzeniach historycznych (Woźniak, 1988, s. 4), organizacjach społeczno-środowiskowych (Bąkowski, 1988, s. 7; Krawiarz, 1988, s. 3; Potocki, 1988, s. 5), losach mieszkańców (Potocki, 1988, s. 3), przedstawiono sylwetki wybitnych kórniczan (Potocki, 1988, s. 4; 1988, s. 5), zajmowano się lokalną twórczością artystyczną i folklorem (Pepel, 1988, s. 5; 1988, s. 5), zamieszczano wspomnienia (Pohl, 1988, s. 3).

Na łamach ówczesnego „Kórniczanina” ${ }^{12}$ pisał między innymi dr Kazimierz Krawiarz ${ }^{13}$, zasłużony regionalista kórnicko-bniński i aktywny działacz Kórnickiego Bractwa Kurkowego oraz Wielkopolskiego Towarzystwa Kulturalnego w Poznaniu. Wśród autorów artykułów, felietonów, esejów, informacji, komentarzy, kroniki, sprawozdań, byli między innymi: Ryszard Bąkowski, Maria Hłyń, Edmund Melosik, Lucyna Pepel, Anna Rauk, Stanisław Potocki.

Jerzy Wisłocki (1988, s. 1) kreśląc obraz zadań współczesnego „Kórniczanina", nawiązał do wspaniałej XIX-wiecznej tradycji tego tytułu, pisząc: „Miesięcznik miał zachęcać mieszkańców miasta i gminy do konsolidacji w okresie zagrażającego im pruskiego naporu. Z. Celichowski, autor większości artykułów, nawoływał do nowoczesnego gospodarowania, zakładania polskich spółek, przedsiębiorstw, warsztatów rzemieślniczych. «Kórniczanin» miał być małym kółkiem w machinie «pracy organicznej»”. Wspomniane XIX-wieczne czasopismo „Kórniczanin”, wydawane przez Zygmunta Cielichowskiego (1845-1923), ukazywało się dwa razy w miesiącu ( 1 i 15 ) od 1 lutego do 15 grudnia 1875 roku (łącznie wydano 22 numery). Periodyk rozpowszechniano w Kórniku, Bninie i okolicy, a jego zainteresowania obejmowały problematykę społeczno-kulturalną oraz oświatowo-wychowawczą. Jak zauważył Marceli Kosman (1978, s. 206): „Celichowski tępił w nim takie plagi społeczne jak karciarstwo, lenistwo, pijaństwo; walczył [...] o moralność, oświatę i dobrobyt". Doktor Zygmunt Celichowski był historykiem, od 1870 roku

12 Szerzej o dziejach „Kórniczanina” w latach 1988-2003 zob.: Kórniczanin 1988-2003, „Kórniczanin” 2003, nr 5, s. 21-23.

13 Doktor Kazimierz Krawiarz jest autorem między innymi opracowania, 100 lat Ochotniczej Straży Pożarnej w Kórniku (Kórnik 2012). Kazimierz Krawiarz pisał także artykuły do wielu wielkopolskich czasopism historyczno-regionalistycznych, w tym między innymi do: „Kórniczanina”, „Kroniki Wielkopolski”, „Naszej gminy Kórnik”, „Przeglądu Wielkopolski”, „Śremskiego Notatnika Historycznego”, „Wielkopolskich Wiadomości Filatelistycznych”, „Ziemi Kórnickiej”. 
zarządcą Biblioteki Kórnickiej („Kórniczanin”, 2003, s. 20; Zagartowska, 1996, s. 9-38).

\section{„Ziemia Szamotulska” (1988-1989)}

Rada Miejsko-Gminna PRON w Szamotułach już w grudniu 1986 roku wystapiła z wnioskiem do GUKPiW o zezwolenie na wydawanie dwumiesięcznika „Ziemia Szamotulska”. Czasopismo zamierzano drukować w formacie A4, objętości 12 stron i nakładzie 3000 egzemplarzy, a kierowanie 8-osobowym zespołem redakcyjnym powierzono Zenonowi T. Pohlowi - sekretarzowi Rady Miejsko-Gminnej PRON w Szamotułach. 7 lutego 1987 roku prezes GUKPiW wydał zezwolenie na wydawanie dwumiesięcznika „Ziemia Szamotulska”. Ostatecznie czasopismo w tej formie nie ukazało się. Niemniej jednak w lutym 1988 roku Rada Miejsko-Gminna PRON w Szamotułach powtórnie zwróciła się do GUKPiW o zezwolenie na wydawanie kwartalnika „Ziemia Szamotulska” w formacie A4, objętości 12 stron i nakładzie 2000 egzemplarzy. Zezwolenie takie GUKPiW wydał 25 lutego 1988 roku. Natomiast w maju 1989 roku wystąpiono do GUKPiW o zgodę na zmianę częstotliwości „Ziemi Szamotulskiej”, którą zamierzano wydawać co dwa miesiące. Takie zezwolenie otrzymano pod koniec maja 1989 roku. Inicjatorami czasopisma byli między innymi Jerzy Bukowski oraz Edmund Zawadzki (przewodniczący Rady Miejsko-Gminnej PRON w Szamotułach).

Najpierw kwartalnik (od czerwca 1988 roku, numery 1-5), a później dwumiesięcznik (od lipca 1989 roku, numery 6-8) Rady Miejsko-Gminnej PRON w Szamotułach pod nazwą „Ziemia Szamotulska” ukazywał się w tej formule wydawniczej stosunkowo krótko, albowiem zaledwie od czerwca 1988 do grudnia 1989 roku na obszarze prawie całego dawnego powiatu szamotulskiego w gminach: Duszniki, Kaźmierz, Obrzycko, Ostroróg, Pniewy, Szamotuły, a także w sąsiednich gminach Oborniki i Rokietnica. Czasopismo, po rozwiązaniu PRON-u, kontynuowało jednak działalność jako dwumiesięcznik Rady Narodowej Miasta i Gminy w Szamotułach (od numeru 9), którą formalnie zakończyło w sierpniu 1990 roku (numer łączony obejmował okres maj-sierpień). Łącznie ukazało się 13 numerów „Ziemi Szamotulskiej”.

Na łamach „Ziemi Szamotulskiej” znajdujemy wiele cennych materiałów poświęconych dorobkowi kulturowemu regionu szamotulskiego, który jest przecież znany w całej Polsce ze swoich osiągnięć w sferze 
folkloru (zwłaszcza w dziedzinie stroju szamotulskiego oraz pieśni ludowej i tańca ludowego), muzyki (Wacław z Szamotuł, nadworny kompozytor króla Zygmunta Augusta), polityki (Jan Ostroróg, kasztelan i wojewoda poznański, stronnik Kazimierza IV Jagiellończyka), działalności społeczno-kulturalnej i regionalizmu, tolerancji religijnej (wsparcie dla reformacji Jana Świdwy Szamotulskiego i Łukasza III Górki, pod którego protektoratem działała w latach 1558-1561 drukarnia Aleksandra Augezdeckiego, brata czeskiego). Wspomnieć w tym miejscu należy, że w Szamotułach już od połowy XIX wieku działały stowarzyszenia o charakterze społeczno-kulturalnym, w tym między innymi: Towarzystwo Zbieraczów Starożytności Krajowych (1840-1846), Komitet Towarzystwa Oświaty Ludowej (1872-1879), Okręg Towarzystwa Czytelni Ludowych (1880-1939), a później powstały następne organizacje i inicjatywy, takie jak Oddział Polskiego Towarzystwa Krajoznawczego (1926-1948), Akademickie Koło Szamotulan (1924-1939), Klub Artystyczno-Literacki „Wietrzne Pióro” (1932-1939). Po drugiej wojnie światowej funkcjonowały w Szamotułach takie stowarzyszenia na przykład, jak: Towarzystwo Miłośników Sztuki i Pięknej Książki (1946-1948), Towarzystwo Miłośników Kultury Ziemi Szamotulskiej (1956-1962), Towarzystwo Kultury Ziemi Szamotulskiej (od 1963), które w okresie 1963-1970 było Oddziałem Powiatowym Wielkopolskiego Towarzystwa Kulturalnego w Poznaniu. Zasługi Szamotuł dla kultury nie tylko regionu wielkopolskiego podniósł w formie poetyckiej Stanisław Helsztyński (1987, s. 1), który w wierszu Miasto wojewodów, uczonych, artystów zwrócił uwagę na bogatą spuściznę kulturową tego miasta.

W zawartości ,Ziemi Szamotulskiej” mamy wywiady z artystami ludowymi (Różański, 1989, s. 1, 11) i opisy instrumentów ludowych (Kłos, 1989, s. 5), informacje o działalności instytucji edukacyjno-oświatowych i stowarzyszeń społeczno-kulturalnych (Czepułkowska, 1989, s. 5; Krygier, 1989, s. 5), doniesienia z wykopalisk archeologicznych, dotyczące nazw miejscowości czy zabytków architektury (Krygier, 1989, s. 7; Łopata-Łowiński, 1989, s. 6; Różański, 1989, s. 8), charakterystykę poszczególnych miejscowości ziemi szamotulskiej i zwyczajów ludowych regionu szamotulskiego (Krygier, 1989, s. 1-2; Mordal, 1989, s. 11).

W skład zespołu redakcyjnego „Ziemi Szamotulskiej” wchodzili między innymi: Wojciech Elsner, Jerzy Kmieciak (redaktor naczelny od numeru 6 do numeru 10), Ewa i Romuald Krygierowie (kierowali redakcją od numeru 11), Marian Różański, Marek Szczepański (redaktor naczelny do numeru 5). Wśród autorów opracowań zamieszczanych w „Ziemi 
Szamotulskiej" znajdowali się na przykład: Krystyna Czepułkowska ${ }^{14}$, Cezary Kłos, Agnieszka Krygier, Ewa Krygier, dr Romuald Krygier (1933-2009) ${ }^{15}$, Janusz Łopata-Łowiński, Paweł Mordal, Marian Różański (13 lat był korespondentem „Głosu Wielkopolskiego”), Marek Szczepański.

Warto również nadmienić, iż zezwolenie Głównego Urzędu Kontroli Publikacji i Widowisk na wydawanie czasopisma otrzymały pod koniec lat 80. także inne lokalne rady PRON-u, którym jednak nie udało się ich uruchomić przed historycznym przełomem politycznym 1989 roku, symbolizowanym rozmowami przy „Okrąłym Stole”. Należały do tych jednostek przykładowo Buk i Lwówek, gminy miejsko-wiejskie położone w dawnym województwie poznańskim.

Rada Miejsko-Gminna PRON w Buku 7 marca 1988 roku wystąpiła do GUKPiW z wnioskiem o wydanie zezwolenia na wydawanie kwartalnika „Ziemia Bukowska”, wskazując Tomasza Łubińskiego redaktorem naczelnym. Jednak dopiero 4 lipca 1988 roku otrzymano taką zgodę. Czasopismo zamierzano wydawać w nakładzie do 2000 egzemplarzy, objętości 8 stron formatu A4. Natomiast zakres tematyczny periodyku powinien obejmować informacje społeczno-gospodarcze, kulturalno-oświatowe, sportowe, które dotyczyły miasta i gminy Buk.

Podobnie postąpiła Rada Miejsko-Gminna PRON we Lwówku, która 21 października 1988 roku wystąpiła do GUKPiW z wnioskiem o zgodę na wydawanie miesięcznika „Echo Lwówka”16, wskazując na

14 Krystyna Czepułkowska jest autorką między innymi opracowania, 40 lat Biblioteki Publicznej im. E. Calliera Miasta i Gminy w Szamotułach (1946-1986) (Szamotuły 1986).

15 Doktor Romuald Krygier (1933-2009) należał do kręgu wytrwałych badaczy regionu szamotulskiego, zwłaszcza jego kultury oraz roli bibliotek w organizowaniu życia społeczno-kulturalnego mieszkańców i upowszechnianiu dóbr kultury. Jest autorem wielu prac fundamentalnych dla regionalizmu szamotulskiego, w tym na przykład: 25 lat bibliotek publicznych w powiecie szamotulskim (1946-1970) (1971); 35 lat biblioteki publicznej Miasta i Gminy im. Edmunda Calliera 1946-1981 (1981); Ich ślad na Ziemi Szamotulskiej (2001); Kolegiata Szamotulska (2001); Szamotulanie znani i mniej znani (1992); Ziemia Szamotulska. Przewodnik wycieczkowy (1965). Romuald Krygier swoje artykuły publikował w wielu czasopismach o charakterze historyczno-regionalistycznym i bibliograficzno-literackim, na przykład w: ,Informatorze Bibliotekarza Wielkopolskiego”, „Nurcie”, „Zeszytach Wielkopolskich”, „Ziemi Szamotulskiej".

${ }^{16} \mathrm{~W}$ ten sposób zamierzano kontynuować wydawanie ukazującego się nieregularnie od 1983 roku powielanego informatora „Echo Lwówka” Towarzystwa Miłośników Lwówka, przeznaczonego do użytku wewnętrznego. Jego inicjatorem był Lech 
funkcję jego redaktora naczelnego Ireneusza Witkowskiego (zasłużonego działacza harcerskiego i społeczno-kulturalnego, przewodniczącego koła Stronnictwa Demokratycznego we Lwówku oraz dyrektora Szkoły Podstawowej w Chmielinku, późniejszego burmistrza Lwówka w latach 2002-2006). Dnia 2 grudnia 1988 roku GUKPiW wydał zezwolenie na wydawanie czasopisma, które obejmowało zgodę na ukazywanie się miesięcznika „Echo Lwówka”, rozpowszechnianego w mieście i gminie Lwówek, a także w ościennych gminach, w nakładzie do 1500 egzemplarzy, objętości 4-8 stron formatu A4 oraz tematyce skupionej na działalności PRON-u, organizacji społecznych i politycznych, organów administracji państwowej, problematyce społeczno-gospodarczej, kulturalnej, ochrony środowiska, rekreacji itp.

W wielu środowiskach czasopisma tego typu były pierwszymi inicjatywami prasowo-wydawniczymi o charakterze zarówno społeczno-politycznym, jak i społeczno-kulturalnym oraz o lokalnym zasięgu rozpowszechniania, w innych zaś nawiązywały do nie ukazujących się od wielu dziesięcioleci tytułów prasowych, na ogół o rodowodzie przedwojennym (Kowalczyk, 2010, s. 106-109). Periodyki te cieszyły się ogromnym zainteresowaniem mieszkańców, spragnionych rzetelnych informacji o przeszłości i dniu dzisiejszym swojej „małej ojczyzny”, oraz pobudzały lokalny patriotyzm. Spełniały więc w społeczności lokalnej ważne funkcje, w szczególności funkcje informacyjna, kulturotwórcza, aktywizacyjną i integracyjną. W ówczesnych warunkach społeczno-politycznych ich zawartość nie była jednak wolna od pewnych ograniczeń tematycznych, zarówno w dziedzinie historii Polski (II RP, 17 września 1939, Katyń, walka z władzą ludowa), jak i idei (między innymi zakaz głoszenia kapitalistycznych $i$ antysocjalistycznych poglądów społeczno-politycznych).

\section{Bibliografia}

I Kongres Patriotycznego Ruchu Odrodzenia Narodowego. Materialy i dokumenty (1983), Warszawa.

Andrzejewski T. (2003), 20 lat $z$ „Echami...” jubileusz pierwszej w Polsce gazety gminnej, „Echa Opalenickie”, nr 5/6.

Mroczkiewicz, prezes towarzystwa, który również kierował redakcją informatora. Czasopismo posiadało format A5, objętość około 12 kolumn, nakład 30-50 egzemplarzy i obejmowało informacje z działalności Towarzystwa Miłośników Lwówka, życiorysy zasłużonych mieszkańców Lwówka oraz skrót informacji dotyczących bieżących wydarzeń w mieście i gminie Lwówek. 
Bąkowski R. (1988), ,Kotwica”- bogatej historii ciag dalszy..., „Kórniczanin”, nr 5.

Biblioteka na łamach prasy... i nie tylko (2000), wybór materiałów i opracowanie Julia Tarczyn, Nowy Tomyśl.

Bobowska I. (2008), Szermierze słowa, „Echa Opalenickie”, nr 7.

Czepułkowska K. (1989), Raport z ksiqżnicy, ,Ziemia Szamotulska”, nr 6.

Deklaracja programowa, kierunki i metody działania, zasady statutowe, uchwalone przez I Kongres Patriotycznego Ruchu Odgrodzenia Narodowego 7-9 maja 1983 r. (1983), Warszawa.

Dziki S. (1991), Uwarunkowania instytucjonalno-organizacyjne, „Zeszyty Prasoznawcze", nr 1-2.

Falecki S. (1984), Prezentacja dorobku kulturalnego miasta i gminy Śrem w Pałacu Kultury w Poznaniu, „Głos Śremski”, nr 6.

Grabowski S. (1988), Na powstańczym froncie. Zapiski historyczne, „Głos Śremski”, nr 12.

Grobelna W. (2012), Jubileusz 125-lecia Towarzystwa Miłośników Ziemi Śremskiej, „Przegląd Wielkopolski”, nr 3.

Helsztyński S. (1987), Miasto wojewodów, uczonych, artystów, w: Szamotuły, oprac. P. P. Prus, Szamotuły.

Henryk Błaż - pedagog, humanista, społecznik. Sylwetka (2001), oprac. L. KończalGnap, Cz. Krolek, Nowy Tomyśl.

Kaczmarek B. (1984), Echa Opalenickie - jakie? „Echa Opalenickie”, nr 3.

Kłos C. (1989), Szamotulska Maryna, ,Ziemia Szamotulska”, nr 8.

Kosman M. (1978), Opowieści Kórnickie, Poznań.

Kościański Z. (1986), Ciekawe sylwetki Nowotomyślan. Ks. prob. Stanisław Kuliszak, wybitny ksiadz, żotnierz i społecznik, ,Wiadomości Nowotomyskie”, nr 1.

Kościański Z. (1987), Nowotomyscy powstańcy, „Wiadomości Nowotomyskie”, nr 12.

Kościański Z. (1988), Ach, te lata dwudzieste..., „Wiadomości Nowotomyskie”, nr 3.

Kowalczyk R. (2002), Wczoraj i dziś prasy lokalnej w Polsce, Poznań.

Kowalczyk R. (2010), Rynek prasy lokalnej w Wielkopolsce 1990-2010. Studium medioznawczo-politologiczne, Poznań-Opole.

Kowalczyk (2012), Współczesna prasa lokalna w Wielkopolsce, Opole.

Kórniczanin od 1 lutego 1875 do 15 grudnia 1875 (2003), „Kórniczanin”, nr 5.

Krawiarz K. (1988), Kórnickie Bractwo Kurkowe (1745-1987), „Kórniczanin”, nr 2.

Krygier A. (1989), Pochodzenie nazwy Szamotuły, „Ziemia Szamotulska”, nr 6.

Krygier R. (1989), Z działalności Towarzystwa Kultury Ziemi Szamotulskiej, „Ziemia Szamotulska", nr 6.

Krygier R. (1989), Ludowe zwyczaje gwiazdkowe w regionie szamotulskim, „Ziemia Szamotulska", nr 8. 
Kupiec S. (2010), ... jestem obciażony historiq - rozmowa z drem Zdzisławem Kościańskim o prawdzie historycznej, narodowej pamięci, mitach dotyczqcych kawalerii, mediach i zobowiazaniach moralnych, „Przegląd Nowotomyski”, nr 2.

Łopata-Łowiński J. (1989), Szamotulskie sensacje archeologiczne, „Ziemia Szamotulska", nr 6.

Łozowski F. (2003), Czesław Krolek (25.06.1935-06.10.2002), „Bibliotekarz”, nr 6.

Mordal P. (1989), Baborówko, „Ziemia Szamotulska”, nr 6.

Mroczek J. (1983), ,, Artykuł polityczny”, „Echa Opalenickie”, nr 4.

Od redakcji (1983), „Echa Opalenickie”, nr 1.

Od redakcji (1984), „Głos Śremski”, nr 1.

Od redakcji (1986), „Wiadomości Grodziskie”, nr 1.

Pepel L. (1988), Rzeźbienie jest dla niej oderwaniem od codzienności..., „,Kórniczanin", nr 1.

Pepel L. (1988), „,Rzeźbi z zamiłowania, głównie dla siebie samego”, „Kórniczanin”, nr 5.

Pismo Miejsko-Gminnej Rady PRONw Nowym Tomyślu z 12 marca 1986 roku (1986), Nowy Tomyśl.

Podsiadły A. (1987), Jan Horowski, „Głos Śremski”, nr 10.

Podsiadły A. (1988), Jan Borowiak, „Głos Śremski”, nr 1.

Pohl J. (1988), Ze wspomnień Jana Pohla, „Kórniczanin”, nr 6.

Potocki S. (1988), Emigracja kórniczan do Ameryki, „Kórniczanin”, nr 1.

Potocki S. (1988), „Biała Dama”, „Kórniczanin”, nr 1.

Potocki S. (1988), Kajetan Wincenty Kielisiński (1808-1849), „Kórniczanin”, nr 2.

Potocki S. (1988), 120 lat Kółka Rolniczego w Kórniku, „Kórniczanin”, nr 6.

Różański M. (1989), Nasze rozmowy z... Mariq Orlik artystkq ludowq Ziemi Szamotulskiej, „Ziemia Szamotulska”, nr 6.

Różański M. (1989), Wodociagi, „Ziemia Szamotulska”, nr 6.

Silski A. (1984), Rok - i co dalej? „Echa Opalenickie”, nr 6.

Silski A. (2013), Tak powstawaty Echa Opalenickie, „Echa Opalenickie”, nr 10.

Tetzlaff W. (1985), Mieszkańcy Śremu w epoce kamienia, „Głos Śremski”, nr 2.

Walczak K. (1986), Szarfa Królewskiego Bractwa Kurkowego, „Głos Śremski”, nr 1.

Wawrzyniak J. M. (1985), Żołnierskie wspomnienia, „Głos Śremski”, nr 5.

Wiadomości Grodziskie (1987), nr: 1-11.

Wisłocki J. (1988), Od tradycji do współczesności, „Kórniczanin”, nr 1.

Woźniak M. (1988), Walka z niemieckim okupantem 1942-1945 (z dziejów konspiracyjnych placówek ,,Topola” i ,Smoła” w Kórniku w latach 1939-1942), „Kórniczanin”, nr 5.

Zagartowska D. (1996), Bibliotekarz, „Pamiętnik Biblioteki Kórnickiej”, z. 24. 
Zastawny K. (1985), Stałe działy ekspozycyjne Muzeum Śremskiego, „Głos Śremski”, nr 5.

Zastawny K. (1985), Dr Seweryn Matuszewski, „Głos Śremski”, nr 8.

Zastawny K. (1986), Feliks Sałaciński, „Głos Śremski”, nr 10.

\section{Local periodicals of the Patriotic Movement for National Rebirth in the Poznań Region from 1983 to 1989}

\section{Summary}

The author characterizes the examples of periodicals published by the Patriotic Movement for National Rebirth (PRON) in the then Poznan Region from 1983 to 1989. The following monthlies were among them: "Echa Opalenickie" (1983-1989), “Głos Śremski" (1984-1989), "Kórniczanin” (1988-1989), "Wiadomości Grodziskie" (1986-1989), "Wiadomości Nowotomyskie" (1986-1989), and a bi-monthly "Ziemia Szamotulska" (1988-1989). The author presents their founders, tasks and content as well as selected authors of materials published.

Key words: Patriotic Movement for National Rebirth (PRON), local PRON periodicals, the Poznan Region from 1983 to 1989 
